\author{
Silvia Tóbias Kosár, \\ PhDr., Faculty of Economics, J. Selye University (Komárno, Slovakia), \\ Renáta Machová, \\ Ing., Faculty of Economics, J. Selye University (Komárno, Slovakia); \\ Monika Šimonová, \\ Mgr., Faculty of Economics, J. Selye University (Komárno, Slovakia)
}

\title{
CREATIVITY IN PRACTICE IN THE CONTEXT OF APPLIED MANAGEMENT METHODS AND TOOLS
}

Management as a discipline is a part of human civilization in many aspects of its nature, while managerial creativity as a basic source of business innovations gained an extraordinary importance in the 21st century. Utilization of economic and human resources is possible by increasing creativity and activating innovative potential of people. Creativity is the pillar of innovation that helps organizations to develop business strategies and contributes to strengthen market position of the organization, as well as differentiates it from others. The use of management tools is essential to improve the work process, ensure efficient performance of the company and succeed in problem solution. The article focuses on creative potential of employees and analysis of applied management methods and tools promoting creativity. No matter what area the company operates in, because the company mission is defined in creativity, innovation and the company's ability to operate efficiently and flexibly. The company uses creativity to strengthen its position on the market and create competitive advantage. While demonstrating our research findings, we will summarize the characteristics of the company, as well as introduce our conclusion of the research.

Keywords: management, creativity, boosting creativity, agricultural sector, Slovakia.

DOI: 10.21272/mmi.2017.2-17

Introduction. Creativity has become an everyday necessity for businesses to maintain their competitive position in rapidly changing business environment. The external environment is changing, which is a constant threat for business, while other businesses recognize new opportunities in change. Creativity in practice is used and applied effectively only with proper use of managerial methods and tools. In today's highly competitive environment it is extremely difficult for businesses to compete, stabilize and strengthen their position on the market, as well as ensure long term competitive advantage. Not only financial assets and natural resources, but creativity is also a tool to economic success. It is one of the best tools to generate and spread innovation in companies. Part of innovative tactics of each company should be the initiation of employees' creativity [6].

Classification of Basic Management Tools and Methods. To certain degree problems of management require individual approach. Attitude, credibility and efficiency have influence on problem solution. Management, as most of the social sciences encounter a problem that it is difficult to distinguish the main factors in scientific research. Management as a scientific discipline uses the following methods [7]:

- Methods adopted from philosophy - help to build a law in development of management. te

- Research methods - different factors are put into context and analyzed. Research in management is very difficult, because negative impact on individuals involved in research must be removed.

- Methods of idealization - findings are abstracted based on research; repeated research is applied to formulate generally applicable rules.

The management process is about applying adequate rules, methods and tools, while guaranteeing effective conversion of resources and ensuring satisfactory conditions to reach the objectives of the company [8] (Fig. 1). 


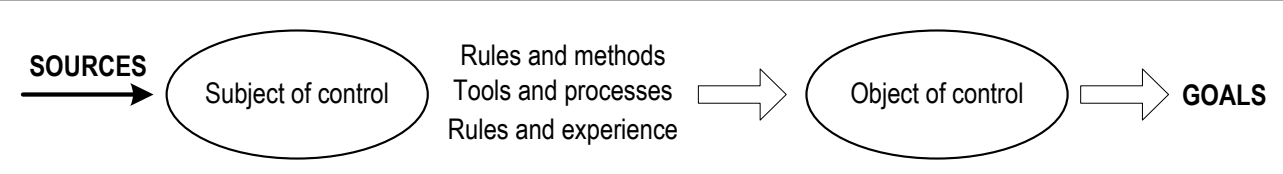

Figure 1 - Management processes [8]

Management Methods and Tools in Business Practice. A method is a way of applying norms and principles, the use of tools and instruments to achieve objectives. Methods can be general logical steps, methods to research real things (typically applied in Sociology, Mathematics, Psychology, Economics etc.), as well as emotional (emotional perception), empirical (surveys, the method of Devil's Advocate, brainstorming). They can also be classified according to features and implementation based on functions. Creativity is necessary to examine in the context of management tasks. These methods include: method of leadership and method of communication. Our research requires classification essential in the field of management:

- management strategy approach (method of analysis and strategy planning)

- practices of human resources management

- financial management practices

- marketing practices

- inventory management practices

- production practices

- procedures for planning and installation IT systems

- quality management practices

- organizational planning practice

- approaches to managing transformation

Decision-making methods play an essential role in management and can be divided as the following [8]:

a) based on characteristic features - heuristic, empirical, accurate

b) based on research method, method of solution

c) based on the nature of the situation - decision making steps in particular situations, uncertainty and risk)

d) based on the degree of algorithmization - methods of systematic and unsystematic decision making

e) factor of decision making - specific and community decision-making process

General Characteristics and the Process of Creativity. Creativity is a variation and realization of new ideas in form of original works of art, cultural products and manufacturing innovations [11].

According to another theory, being creative cannot be approached through some of our past and current investigations. Only partial answers can be found what sense of creativity might mean. Several disciplines: Psychology, Text and Cultural Studies, Sociology, Ecology, Natural Sciences, Educational Theory and Practice, Economics, Philosophy, etc. deal with creativity [5].

The process can be regarded as threefold:

- talent - natural ability or aptitude, figure out something new or create ideas through connections, changes or by reinventing existing ideas.

- relationship - relationship of the individual to whom acceptance and approval of change is essential, as well as attention to play with ideas and flexibility to change opinion.

- course - is a process of hard work, continuous thinking with a focus on solution.

Types of creativity:

- individual vs group,

- professionally oriented vs. user level,

- arbitrary vs. cultural, 
- multilateral vs. multifunctional,

- logico-analytical vs emotional [1].

The main factors of creativity include: fluency - can help to create a lot of thoughts and ideas, flexibility - helps us to overcome certain problems, eccentricity- represents unique ideas and certainty, provides an ability to recognize things from another's perspectives. Another factor is elaboration, where details of solution are unified and finally sensitivity, which identifies problem where the problem does not exist [4].

Characteristics of the creative process and its stages are described by Wallas [15], who defines a four-stage model of the creative process (Fig. 2).

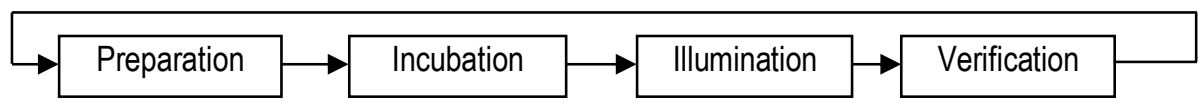

\section{Figure 2 - The creative process [15]}

Preparation is a process, where problems are identified and information is obtained. The individual is collecting information about the problem, identifies the main objective and sets hypothesis considering the problem. During the preparation process the individual should pay attention how to address barriers, examine them and reflect on how to resolve them.

Incubation is considered to be an unconscious processing of the problem. It takes time to arrange data collected in preparation stage. The mentioned two stages require a long period of time, which can be roughly estimated. During Incubation we do not consciously deliberate on a particular problem and a series of unconscious, involuntary mental events are taking place.

Illumination is a very short stage, also called the insight stage. With insight it is really the idea of the "Eureka" moment. An instant inspiration is recognized, inspired by a certain apprehension that something important is to happen. This inspiration can involve emotions from external sources, where the authorship of the individual is questioned as the individual acts as an inactive participant in an immediate inspiration.

Verification stage is characterized by a deliberate effort in the way of testing the validity of the idea and reducing the idea itself to an exact form. The verification stage includes presentation and communication of the final result to let professionals react and use creativity [3].

The Essence of Creativity in Management. Creativity is an act, when new values, ideas and thoughts (something original) are generated. Its importance in management is often combined with an ability to invent and think differently. Even a thought itself to generate new ideas and endless ways of thinking can contribute to success. Innovative activity and creativity is important to harmonize in the organization in order to meet the business needs and possibilities of the organization [2].

Creativity in management will support effective and successful business management. The managerial creativity covers two essential parts [14]:

- economic activity, products - creativity is important to manufacture products, improve the quality of services, sales, marketing tactics and cost limits to achieve competitive advantage.

- employee management, creative atmosphere - communication, cooperation in team, cooperation between company management and employees, motivation of employees to contribute with new ideas, finding new solutions to problems.

The success of managers depends on their intellectual skills and utilization of management methods. Managers can provide not only new ideas, but productive solutions for problems as well.

Managerial and entrepreneurial creativity is essential to set strategy, develop projects or solve problems. Employees should develop their creative thinking and should be guided to take an active part 
in the creative process and learn how to implement creative ideas into practice (Mikuláštik, 2010).

Research Methodolgy. The main research objective was to analyze the applied tools in order to enhance creativity in business practice. We applied structured interiews with executives and questionnaire survey with employees [13]. The survey took place from January to August 2016. Initially it was conducted in the company, which currently ranks among the most prominent enterprises in the Slovak agricultural sector. The company has been operating on the Slovak market for 21 years. During its existence it has managed to establish a service network and service of backup parts ensured by professionnally trained personnel. To ensure overall technical support, the company enables its customers to join an unofficial "shopping and marketing association", which was established to reduce the costs of purchasing inputs for agricultural production. This package of services includes the sale of seeds, pesticides and fertilizers of various businesses operating on the Slovak market. The company has been involved in development, production and sale of its own foliar fertilizer.

In the second phase of our research we examined the tools supporting creativity, as well as the methods increasing efficiency in further 150 companies. The research results evaluate practices of companies involved in our survey. The questionnaire survey was conducted in corporate entities operating and headquartered in South Slovakia. Research data was provided by the database of National Statistical Office and Business Register of the Slovak Republic. Our main objective was to involve the widest scope of businesses into the survey. Electronic form of data collection was preferred to minimize costs. Various information security procedures are applied to ensure the credibility of the questionnaire survey. Partially completed questionnaires were excluded from the survey. The research sample is based on fully completed questionnaires returned by 150 companies. We chose businesses operating in agricultural sector, because there is development potential in agricultural businesses in Southern Slovakia. Tender invitations published by the government provide possibilities for agricultural companies. Reorganization of existing companies and increase their efficiency requires the development of knowledge-based economy.

The implementation of our research was proceeded by analysis of secondary data, including the review of domestic and foreign scientific literature, systematization of collected data, utilizing data of international research results (statistical databases, research reports). An important research in the field was made by Michael West and Claudia Sacramento, who researched the factors affecting the level of creativity in organizations [16]. Random sampling methods were used to conduct the survey. We applied a variety of multivariate statistical methods, as well as qualitative testing methods were used. Statistical tests are based on univariate variance analysis, where the variables were analysed independently. Bivariate analysis involves the analysis of two variables for the purpose of determining the empirical relationship between them. It is considered to be a form of quantitative analysis. Multivariate data analysis refers to statistical technique used to analyse data that arises from more than one variable to see how they relate to each other. A summary of methods we applied in our research is demonstrated below (Table 1).

Results. It does not matter what field the company operates in, because mission of the company is based on creativity, innovation and ability of the business to operate effectively and flexibly. Creativity is a basic tool to maintain competitive advantage and strong position on the market. First part of the research summary will introduce the characteristics of the chosen company, followed by the analysis of research results. We find it important to introduce the importance of creativity in the chosen company, because it is a basic pillar of our research. The research analysis contributes to implementation of deductive logic during formulation of hypotheses.

Research findings - Measuring Creativity in Enterprises (Strausová, 2016). To collect research data 580 questionnaires were distributed (January-April, 2016), 250 were returned and 227 were valid with $55 \%$ of respondents being female and $45 \%$ male. We addressed 15 managers for structural 
interview. In terms of age, the largest group of respondents consisted of employees aged 21 to 30 $(37 \%)$. The second largest group (35\%) is formed by employees in the age group of $31-40$ and the smallest group of respondents (28\%) is represented by age group 40 and over.

Table 1 - A summary of methods (authors' systemized based on [17, 18])

\begin{tabular}{|c|c|}
\hline Analysis & Description \\
\hline Average & $\begin{array}{l}\text { the central value for a data set; applied in case of collected data with a help of interval and ratio } \\
\text { measurement scales }\end{array}$ \\
\hline Deviation & Is a measure of difference between the observed value of a variable and some other value \\
\hline Mean squares? & $\begin{array}{l}\text { The mean square of set of values is the arithmetic mean of the squares of their differences from } \\
\text { some given value }\end{array}$ \\
\hline Skewness & Is a measure of symmetry, or more precisely the lack of symmetry \\
\hline Kurtosis & Measures the tailedness of the probability distribution as opposed to the peakedness in the centre. \\
\hline Contingency table & $\begin{array}{l}\text { It displays the frequency distribution of the variables; examines the relationship between two or } \\
\text { more variables. Statistical results of contingency table are the following: Chi-squared test } \\
\text { (examines systematic relationship between two variables), Phi coefficient (measures the degree of } \\
\text { association between two binary variables), Contingency coefficient (estimates the extent of the } \\
\text { relationship between two variables; shows the strength of a relationship), Cramer's } V \text { (examines } \\
\text { the strength of a relationship), Lambda coefficient (index of predictive association) }\end{array}$ \\
\hline Analysis of variance & $\begin{array}{l}\text { ANOVA is a statistical method used to test differences between the average of two or more } \\
\text { variables. Normal distribution of dependent variable and homogeneity of variance are conditions to } \\
\text { apply the analysis of variance. To examine the homogeneity of variables the Levene's test was } \\
\text { applied. Univariate analysis of variance was used to prove the hypothesis. To analyse the null } \\
\text { hypothesis F-test was used; in one case we applied Two-Sample T-Test. P-value at } 0,05 \text { was } \\
\text { applied to measure how compatible the data is with the null hypothesis. If significance level of F- } \\
\text { test is lower than } 0,05 \text {, the null hypothesis is rejected. T-test is used especially in testing } \\
\text { hypotheses. T-Test assesses whether the means of two groups are statistically different from each } \\
\text { other. }\end{array}$ \\
\hline Factor analysis & $\begin{array}{l}\text { A statistical method with a focus on data reduction and summary of variables. Variables obtained } \\
\text { through factor analysis can be used as basic variables in multivariate analyis. To analyse research } \\
\text { data the following were applied: correlation matrix (analysis of correlation coefficients), Bartlett's } \\
\text { Test, Kaiser-Meyer-Olkin indicator (test for sampling adequacy). Principal component analysis, as } \\
\text { a type of factor analysis was applied. }\end{array}$ \\
\hline
\end{tabular}

$19 \%$ of the respondents have a position in the economic department and $17 \%$ are employed in sales and marketing. Administration and service employ $14 \%$ of the respondents, the personnel accounts for $13 \%$ and $6 \%$ work in production.

Creativity is an ability to generate new ideas, thoughts, develop creative thinking and solve problems in unusual way. Respondents define creativity as the basis of innovation and an ability oriented at problem solution, as well as the company uses creativity to gain competitive advantage. The smallest rating was given to the fact, that creativity can be found within a company, but it is still among characteristic categories of creativity assessment. High variation values indicate diversified assessment of respondents.

According to company managers creativity is defined as imagination, ingenuity, originality and innovation. This definition is associated with generating new ideas, creating new things and come up with solutions in professional and private life. The age group 21-30 found creativity important because of innovation, competitive advantage and an ability to solve problems. Options indicate very small differences. Similar opinion was provided by the age groups $31-40$ and the group 40 and over. Creativity increases teamwork in a workplace. Employees of the company are familiar with the concept of creativity and consider it to be a vital necessity of the company to function effectively and flexibly on the market. An enterprise may use various forms of creativity to achieve huge growth and open communication within an organization. It can also be used to increase competitive advantage and effective cooperation in team. 
Based on managerial interviews the company mainly benefits from team creativity. Teams generate new ideas, develop new products and expand their porffolio in agriculture, food industry and automotive industry. Creativity plays an important role in developing new products and creating advertisements. Figure 3 shows the opinion of 14 employees, aged 21-30. The company benefits from team creativity, where individuals are open to mutual ideas. Nine employees in the same age group pointed out creativity of the top management and seven employees emphasized specific creativity. More than ten employees aged 31-40 marked creativity of top management, which represents the basic pillar between the manager and an employee relationship. Ten respondents in the same age group marked team creativity and only seven respondents marked specific creativity. Employees, aged 40 and over voted on team creativity, seven respondents believe that the business benefits from management creativity. Only two employees marked an answer of specific creativity. The answers show, that the company benefits most from team creativity, which helps them in dissemination and sharing knowledge to generate ideas and develop products, as well as solving problems.

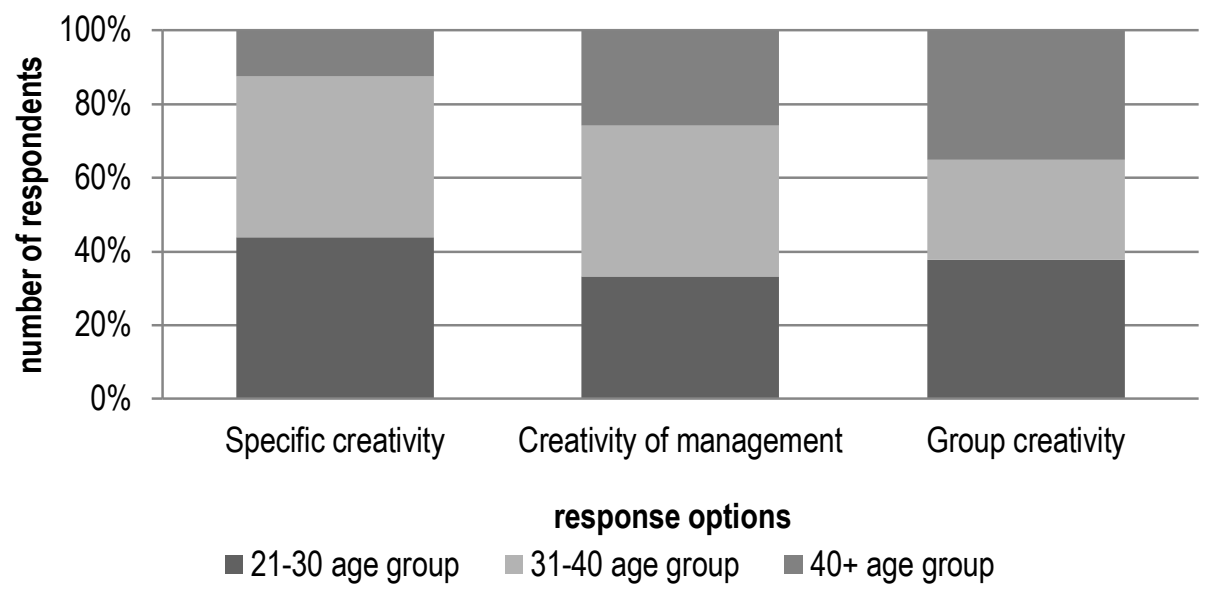

Figure 3 - Creativity in Enterprise (findings based on questionnaire survey)

There are many factors that affect creativity e.g. knowledge, thinking and behaviour of employees. The opinion of employees and managers is different according to results (Figure 4).

According to company managers significant impact on creativity have the following factors: stress-free work environment, excellent team atmosphere, positive attitude to work, employee motivation and flexibility. Based on the answer of 16 employees (21-30 age group) creativity is important in motivation to complete work. A bit less than 14 employees considered specific knowledge, creative thinking and external environment an important factors affecting creativity. The remaining 9 employees ranked creative behaviour important. 19 respondents (31-40 age group) marked creative thinking as the main factor of creativity. Furthermore, 11 to 12 respondents consider specific knowledge and external environment as factors that affect creativity. Only 10 respondents think that creative behaviour and motivation have significant impact on creativity. 16 employees (age group 40+) believe that creative thinking is a major factor influencing creativity. 14 respondents marked creative behaviour, 10 respondents marked motivation and 9 respondents found specific knowledge an important factor affecting creativity. Only 4 respondents answered that external environment has deep impact on creativity. Most employees believe that creative thinking contributes to creativity and it is an important factor to develop it. 
С.T. Косар, Р. Махова, М. Шимонова. Творчість в практиці в контексті прикладних методів та інструментів управління

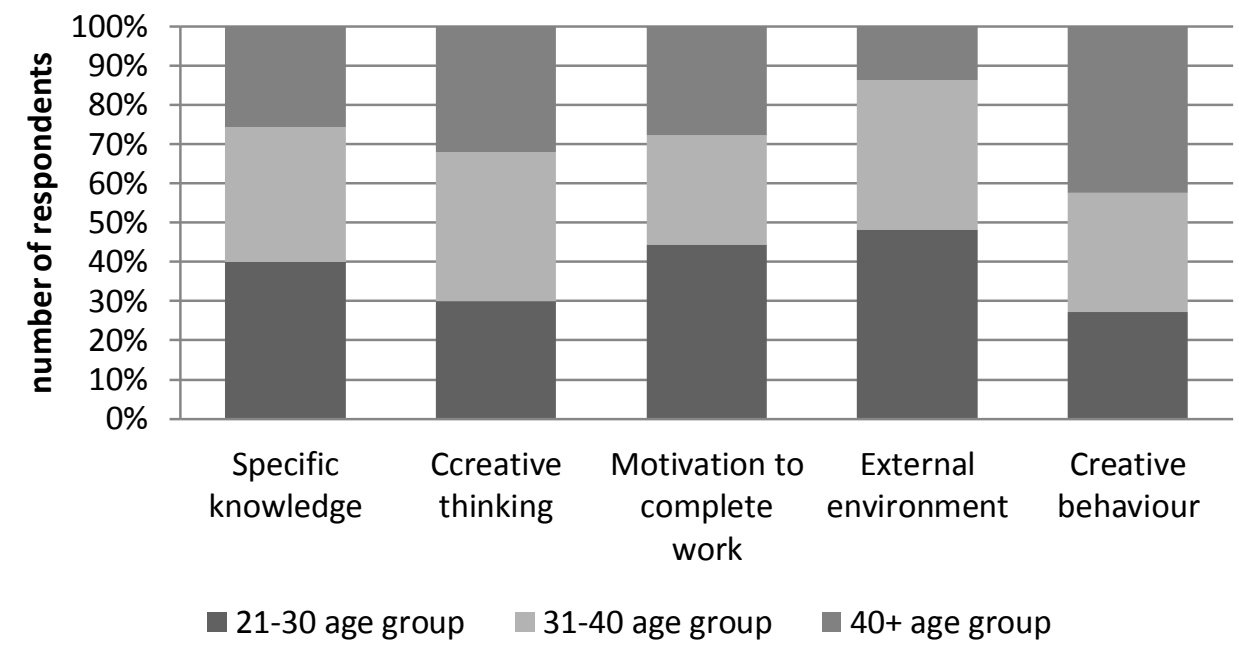

Figure 4 - Factors affecting creativity (findings based on questionnaire survey)

Businesses face certain barriers that have negative impact on creativity. Building creativity in teamwork can be hampered by stress, onerous work, finances, etc. By asking this question we wanted to find out the extent to which the company can face obstacles they want to remove.

We can assume that workplace stress, financial barriers, time pressure and misunderstanding are the main factors that have significant impact on workplace creativity (Figure 5).

Workplaces should be stress-free with friendly atmosphere and great team. Figure 10 demonstrates that up to 20 respondents (21-30 age group) marked workplace stress a negative factor, 17 respondents complained about onerous work, 14 respondents marked time pressure and 12 employees listed other options affecting creativity. The mentioned options are: stereotyped work, automation, unnecessary tasks and bureaucracy. 21 respondents (31-40 age group) consider workplace stress as the main obstacle to creativity. 18 respondents mentioned time pressure as an existing barrier. Challenge as an obstacle was mentioned by 4 respondents. The age group 40+ marked workplace stress and time pressure. Nine respondents mention other factors e. g. superiority and lack of self-expression. The answers reflect problems the company faces and should eliminate them as quickly as possible. It is convenient for the company to have only few barriers to maintain its competitive advantage and significant market position.

To develop their productivity companies should develop creativity. More creativity companies apply, more likely they will produce quality products. They have to use motivation techniques to achieve it. Companies use different motivation techniques to increase creative productivity. They provide financial and non-financial incentives, work in multidisciplinary teams, various trainings and teamwork to develop employee creativity. Creative methods are usually applied to develop creative thinking, generate new ideas, develop new products, solve problems and expand knowledge and communication in a company. 


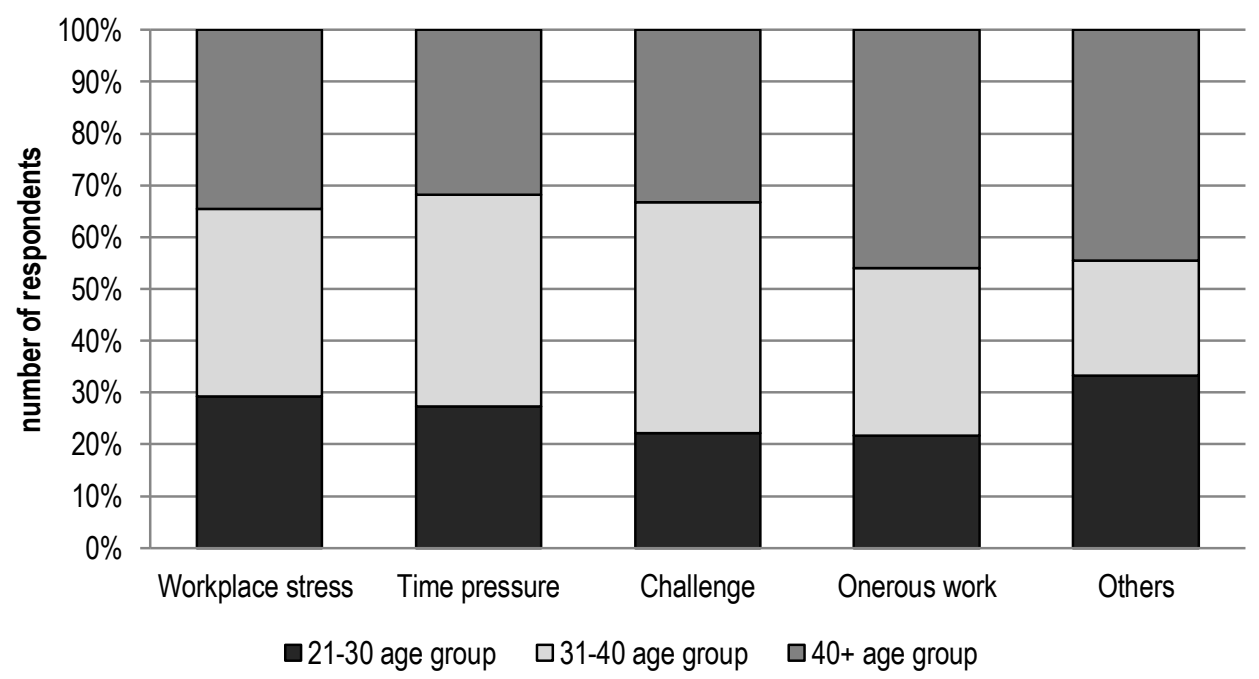

Figure 5 - Negative factors affecting creativity (findings based on questionnaire survey)

Respondents of the survey had to evaluate creativity on a Likert Scale. Responses are coded from 1 to 5 , where 5 stands for "strongly agree" and 1 stands for "strongly disagree" (Table 2)

Table 2 - Creative techniques used in the company (based on findings of own research)

\begin{tabular}{|c|c|c|}
\hline Creative techniques: & Average & Variation \\
\hline brainstorming & 2,63 & 1,164 \\
\hline multidisciplinary/ multi-functional teams & 3,56 & 1,228 \\
\hline employee training & 3,82 & 1,202 \\
\hline rotation of staff in the company & 2,8 & 1,315 \\
\hline financial incentives & 2,87 & 1,140 \\
\hline self-characterization & 2,75 & 1,056 \\
\hline measuring different mindset & 2,8 & 1,17 \\
\hline analysis of life goals & 2,91 & 1,252 \\
\hline characterization according to other employees & 3,11 & 1,168 \\
\hline non-financial incentives & 2,86 & 1,501 \\
\hline
\end{tabular}

The most creative technique is proved to be the employee training, followed by multidisciplinary/ multi-functional teamwork and characterization provided by other employees. Less typical technique we can find brainstorming. The opinion of respondents largely deteriorates from the average and the results are not homogeneous. The respondents' answers deteriorate regarding the creativity techniques applied in the company.

According to company managers, the company is trying to implement techniques of creativity. If they want to remain successful, they should invest into employee development. To expand creative thinking and generating new ideas each of the employees need to be trained. Based on the responses of age group 21-30, the most relevant techniques e.g. employee training, multidisciplinary / multi-functional teamwork, self-characterization, characterization provided by other employees, non-financial benefits to improve creativity are applied in equal measure by the management. Less important creative techniques 
applied by the company are: brainstorming, staff rotation, measuring different mind-set, financial incentives and analysis of life goals. Equal importance is given to multidisciplinary/multi-functional teamwork and employee training in the group of respondents aged 31-40. These were considered to be the most important tools of creativity. Lower importance was given to all other techniques of creativity. The 40 and over age group identified employee training as the most important method of creativity. Respondents gave lower ratings to multidisciplinary/multi-functional teamwork, staff rotation, financial incentives, analysis of life goals and characterization provided by other employees.

When developing new products, creativity and imagination are vital. To achieve high level of productivity the organization has to utilize the most appropriate means e.g. time, teamwork, playfulness, finances and many other factors. The following table 3 shows respondents attitude towards generating new ideas. Respondents had to provide answers on a scale 1-5 (5 - strongly characteristic, 1 - not characteristic at all).

Table 3 - Generating new ideas (based on findings of own research)

\begin{tabular}{|l|c|c|}
\hline \multicolumn{1}{|c|}{ Generating new ideas: } & Average & Variation \\
\hline work in team & 3,87 & 1,125 \\
\hline time & 4,1 & 0,697 \\
\hline finances & 3,76 & 0,921 \\
\hline persistence & 3,83 & 0,928 \\
\hline playfulness & 3,42 & 1,15 \\
\hline influence of external environment & 3,35 & 1,125 \\
\hline dissemination of knowledge & 3,93 & 0,835 \\
\hline open communication & 4 & 0,85 \\
\hline marketing & 3,43 & 1,057 \\
\hline previous experience & 3,82 & 1,049 \\
\hline
\end{tabular}

Results can prove that time is the most important factor while generating new ideas. Open communication, dissemination and sharing knowledge are also considered to be important factors. The influence of external environment figures as less important factor. The table shows that all factors are important to generate new ideas. High deterioration of values does not provide homogeneous answers. The smallest standard deviation is recognized with option of "time" $(0,69)$, which shows that perception of the respondents is the closest in case of this factor.

The company involved in our research is effectively involved in generating new ideas and developing products. Factors contributing to generate new ideas are: target group, cooperation in team, stress, finances, motivation, stress-free environment, time and imagination. Respondents of the age group 2130 marked teamwork, time and open communication the most important factors. Other respondents emphasized the importance of finances, dissemination of knowledge, previous experience, persistence, playfulness, impact of external environment and marketing. Respondents aged 31-40 develop new ideas on the basis of time, dissemination of knowledge and persistence. They considered other options less important. According to age group 40+, the most important factors in creating new ideas are: teamwork, time, persistence, dissemination of knowledge and previous experience.

Creativity in Enterprises. Most of the business units $(37,2 \%)$ started their business activity 10 years ago. $34.5 \%$ of the businesses have been operating for $6-10$ years, while $27,2 \%$ of them have been on the market for $1-5$ years. $1.1 \%$ of our sample is made up of enterprises operating for less than a year. The ratio of respondents: big enterprises $(5,8 \%)$, small enterprises $(13,1 \%)$, medium enterprises $(72,8 \%)$ and micro-businesses $(8,3 \%)$. Self-entrepreneurs were not involved in the survey. Most of the businesses in the survey are characterized by labour-intensive production and services, but considered 
their activity knowledge and information- intensive.

We used a cross-analysis to examine the relationship between company creativity and company type. According to Pearson's Chi-square test there are two variable significants $(x 2=8,85, d f=2, p=0,03)$. To determine the nature of relationship we applied Cramer's $V$ analysis (Cramer's $V=0,175)$. We can recognize a weak, but positive relationship between the goal and type of creativity used by the company. The success of creative activities in these companies is determined by clear objectives.

Successful cooperation is a key to increase efficiency. Respondents $(57 \%)$ found team creativity the most efficient type of creativity, because individuals and teams are open to new ideas and possibilities (Figure 6). 23\% of respondents found the employee - manager cooperation the most important. Organizational creativity is characterized by high risk and preferred by $20 \%$ of the businesses. Group creativity is an application of methods and techniques implemented by corporate groups e.g. brainstorming, training.

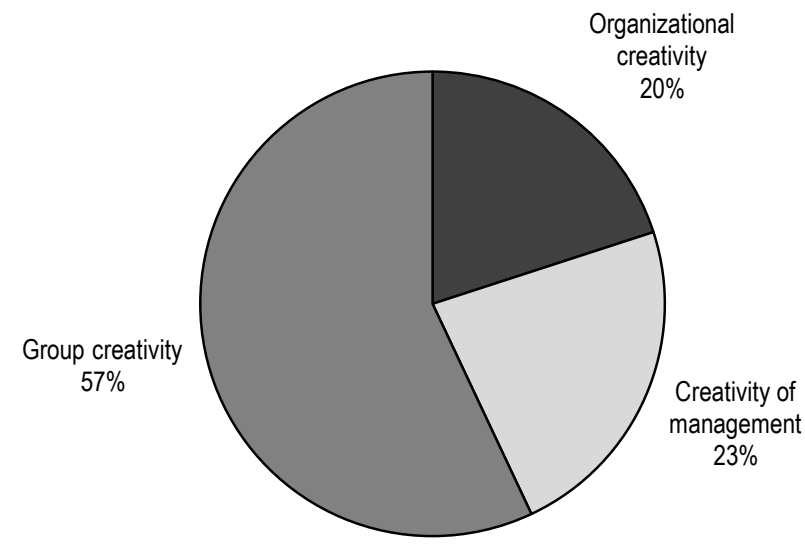

Figure 6-Type of creativity applied by respondents (questionnaire survey)

An appropriate, creative method should be applied to increase efficiency. We used variance analysis to analyse the relationship between the methods of creativity and success of objectives. Several conditions must be met to conduct variance analysis. As a first step, the dependent variable must be normally distributed. This was checked by Kolmogorov-Smirnov and Shapiro-Wilk nonparametric test. The variables have not proved to be normally distributed, but they approached normal distribution (distribution was skewed), so the analysis was carried out. The variables fulfilled the conditions of Levene's test of homoscedasticity. In case of brainstorming, non-financial benefits, self-assessment, measuring different mind-set, analysing life goals and assessment made by others there is no significant difference between the applied techniques of creativity and the objectives set by respondents. However, it has an impact on the success of objectives, if companies choose teamwork (sig. 0,006, $p<0,05$ ), employee training (sig. $0,009, p<0,05$ ), rotation of employees (sig. $0,004, p<0,05$ ) or financial support (sig. $0,031, p<0,05$ ) as a tool of creativity.

In our research we analysed the factors affecting creativity of businesses (Figure 7). We used deductive logic to gain results from secondary research data.

Creative thinking $(28 \%)$ and motivation to complete work $(20 \%)$ have the greatest impact on creative work of employees. Smaller impact on employee creativity (15\%) has the external environment (legal and economic regulations, infrastructure). 
C.T. Косар, Р. Махова, М. Шимонова. Творчість в практиці в контексті прикладних методів та інструментів управління

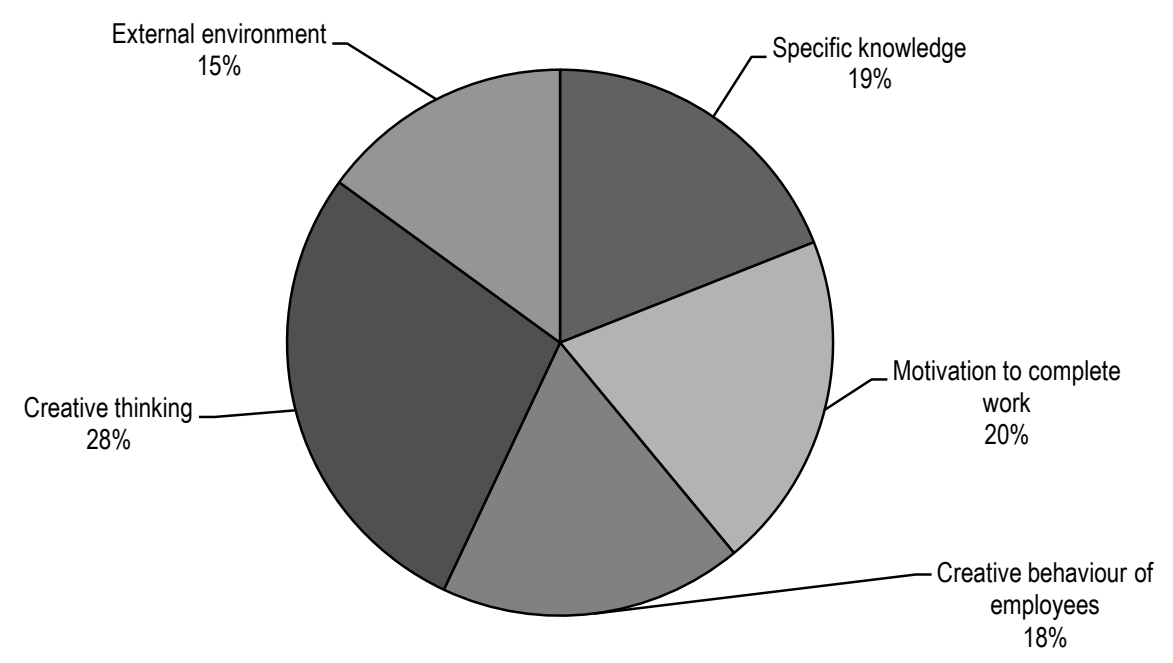

Figure 7: Factors affecting creativity (questionnaire survey)

Creative work can face numerous obstacles. According to secondary research data, workplace stress, deadline pressure, lack of challenges and high burden of employees are the main negative factors influencing creativity (Figure 8).

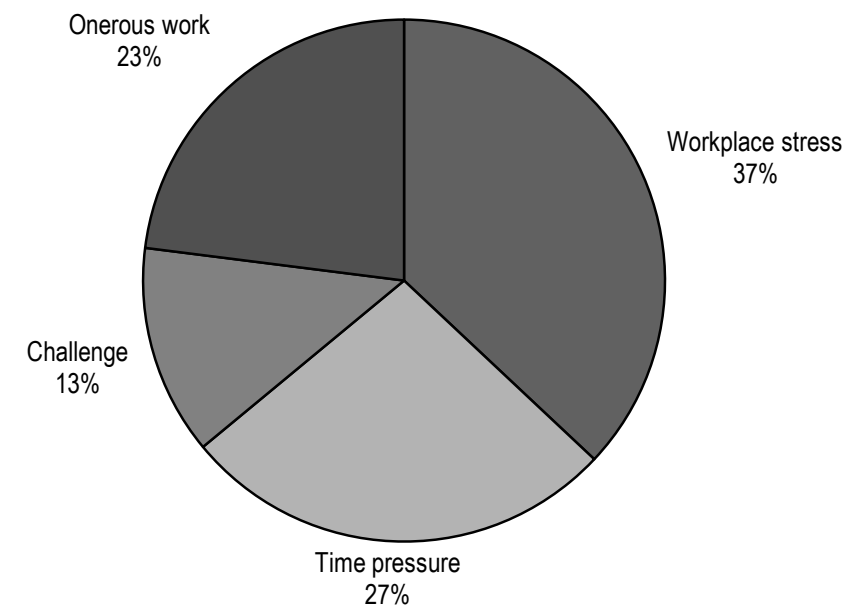

Figure 8 - Factors hindering creativity (questionnaire survey)

Businesses involved in research find workplace stress $(37 \%)$ and time pressure $(27 \%)$ the main obstacles of creative work. Other restraining factors mentioned are the lack of workplace motivation and lack of trust.

Successful workplace creativity depends on open attitude of employees. We examined the answers of respondents about the characteristics of creative employees (Table 4). 
Table 4 - Characteristics of creative employees (questionnaire survey)

\begin{tabular}{|l|r|}
\hline & Average \\
\hline Creativity in my work is important & 4,00 \\
\hline I am interested in the ideas/views of other employees & 3,73 \\
\hline I am not influenced by any conditions & 3,71 \\
\hline I am flexible to solve problems & 3,70 \\
\hline I have logical, rational approach to problem solving & 3,63 \\
\hline I like taking risk & 3,49 \\
\hline Workplace stress is an obstacle to my creativity & 3,46 \\
\hline I feel self-confident & 3,33 \\
\hline Other employees find me creative & 3,05 \\
\hline I seek inspiration in my work & 2,42 \\
\hline
\end{tabular}

The results above show, that creative employees involved in our survey are characterized by recognizing the importance of creativity $(4,00)$, respecting the advice and opinion of colleagues $(3,73)$, ability to exclude conditions $(3,71)$ and flexible problem solving ability $(3,70)$. Based on principal component analysis we grouped the characteristics of creative employee into one single factor. The aptitude tests show significant correlation $(p<0,01)$. According to anti-image covariance matrix, $19 \%$ of elements outside the main diagonal exceed the value of 0,09 , that matches the inch rule. The anti-image correlation matrix shows an MSA (Measures of Sampling Adequacy) values 0,72-0,84. The significance of variables according to Bartlett test is lower than 0,05 . The Kaiser-Meyer-Olkin criterion is also met, since the KMO value is 0,71 and can be properly analysed. Factors with the highest weigh can be considered an ability to recognize creativity, being open to ideas of others and flexible problem solving ability.

The research results indicate that there is connection between encouraging creativity and the creativity of employees. The conditions of homoscedasticity in variance analysis are not met in case of two variables (others find me a creative employee, I seek inspiration in my work), so these were excluded from further analysis. In case of other elements, the Levene's test values are in interval of $1,77-0,45$ and the significance exceeds the required value of 0,05 . The F-test value is between $8,2-2,7$ and significance level is $p<0,05$.

Conclusions and the future research. Nowadays creativity has a significant importance. It helps organizations to respond to changes in an increasingly competitive environment. Some companies did not realize the development and cannot turn opportunities to their advantage, as well as fail to outperform emerging threats. On the other hand, there are companies that can predict their future and create it. Creativity is a long-term management strategy, considered to be a key process. It focuses on products and services, creating better competitive advantage for the company [11].

The concept of creativity is known both for managers and employees, because they consider it important for the company to function effectively and flexibly on the market. We can conclude that motivation to complete tasks; specific knowledge, creative thinking and external environment have impact on creativity. There are some factors, which have negative impact on creativity. These factors are: workplace stress, onerous work, time pressure, stereotypical work, bureaucracy and automation. Based on our survey results we can confirm, that employees evaluate their company as mechanical and also organic, because the organization can adapt to stable, as well as changing conditions. The main objective of the business is to improve its products and services. The management is trying to develop the creativity of employees. Results also indicate that the organization is using motivation techniques to enhance creative productivity. It offers employees financial and non-financial incentives for development, multidisciplinary teams, various seminars and trainings, self-realization, analysis of life goals and variety 
of games in teams to improve creative thinking. The company is using utilizing factors, important to generate new ideas e.g. time, finances, persistence, dissemination of knowledge, open communication, marketing etc. Knowledge has enormous impact on creativity, because each employee is required to have enough knowledge to be able to develop skills, creativity and generate ideas. Employees of the company are flexible, self-confident, solve problems logically and rationally, creative in their work, listen to views and ideas of colleagues and find creativity an important factor in their work. The main characteristics of creative employees are: flexibility, openness to change, commitment to work, selfconfidence, preservice and playfulness.

While analysing further companies operating in agricultural sector, it is important to harmonize the company objectives with the techniques supporting creative work. To achieve successful results, staff trainings and appropriate delegation of tasks is important. Creative thinking and successful work are the most characteristic factors of creative work. The efficiency of workers is negatively affected by time pressure and workplace stress. In organizations involved in survey, creative employees are characterized by recognizing the importance of creativity, openness to information and ability to work flexibly. The efficiency of workplace creativity is influenced by appropriate incentives.

Acknowledgement. Thank you very much for the support of the J. Selye University in research and prof. Ing. Jaroslav Belás, PhD. for expert advices.

1. Ali Taha, V., \& Tej, J. (2012). Tvorivé metódy v manažmente. Prešov: Prešovská univerzita [in Slovac].

2. Bilton, C. (2007). Management and Creativity (From Creative Industries to Creative Management). UK: Oxford, Blackwell Publishing.

3. Franková, E. (2011). Kreativita a inovace v organizaci. Praha: Grada Publishing.

4. Gáborová, L'. (2003). Tvorivost' - techniky rozvíjania tvorivosti. In: Kubáni, V. Sociálno-psychologický výcvik. Prešov: Prešovská univerzita [in Slovac].

5. Hecq, D. (2012). The Creativity Market: Creative Writing in the 21st Century. UK: British Library.

6. Krátka, Z. (2013). Časopis znalostnej spoločnosti: Využívanie metód pre stimuláciu nových myšlienok a kreativity zamestnancov podnikmi $v$ Slovenskej republike. International scientific journal, 2 (1). Retrieved from http://jks.euin.org/sites/default/files/jks_2013_02_Kratka_0.pdf [in Slovac].

7. Malejčík, A. (2010). Základy manažmentu. 4. vyd. Nitra: SPU [in Slovac].

8. Míka, V.T. (2006). Manažérske metódy a techniky. Žilina: Žilinská univerzita. Retrieved from http://fsi.uniza.sk/kkm/files/publikacie/mmt.pdf [in Slovac].

9. Mikuláštík, M. (2010). Tvořivost' a inovace v práci manažera. Praha : Grada Publishing [in Czech]

10. Mura, L., \& Horváth, P. (2015). Some Aspects of Human Resource Management. In: SGEM 2015, Book 1: Psychology and psychiatry, sociology and healthcare, education conference proceedings, vol. I Book Series: International Multidisciplinary Scientific Conferences on Social Sciences and Arts.

11. Mura, L., \& Sleziak, J. (2015). Innovation and Entrepreneurship Network. CERS 2014: 5th Central European Conference in Regional Science, International Conference Proceedings (pp. 643-651).

12. Papula, J., \& Papulová, Z. (2010). Strategické myslenie: za tajomstvami strategického myslenia. Bratislava: Kartprint [in Slovac]

13. Strauszová, M. (2016) Analýza manažérskych metód a nástrojov na podporu kreativity v podnikovej praxi. Master thesis. Komárno: EF UJS [in Slovac].

14. Suntingerová, L'. (2004). Kreativita v manažmente. Bratislava: Vydavatel'stvo Ekonóm [in Slovac].

15. Žák, P. (2004). Kreativita a její rozvoj. Brno: Computer Press [in Czech].

16. Henry, J. (2006). Creative Management and Davelopment. 3rd edition. UK: Sage Publications Ltd.

17. Malhotra K., N. (2002). Marketing-kutatás. Budapest: KJK Kerszöv [in Hungarian].

18. Sajtos, L., \& Mitev, A. (2007). SPSS kutatási és adatelemzési kézikönyv. Budapest: Alinea Kiadó [in Hungarian].

T.C. Косар, PhDr., Економічний факультет, Університет ім. Яноша Шейе (м. Комарно, Словаччина);

P. Maхова, Ing., Економічний факультет, Університет ім. Яноша Шейе (м. Комарно, Словаччина);

M. Шимонова, Mgr., Економічний факультет, Університет ім. Яноша Шейе (м Комарно, Словаччина)

Творчість в практиці в контексті прикладних методів та інструментів управління

Менеджмент як дисципліна є частиною людської цивілізації в багатьох аспектах її природи, а управлінська творчість як основне джерело бізнес-інновацій набуло виняткового значення в XXI столітті. Використання 
економічних і людських ресурсів можливе за рахунок збільшення творчості та активізації інноваційного потенціалу людей. Творчість - це стовп інновацій, який допомагає організаціям розробляти бізнес-стратегії та сприяє зміцненню ринкових позицій організації, а також відрізняє її від інших. Використання інструментів управління має важливе значення для поліпшення робочого процесу, забезпечення ефективної роботи компанії та успішного вирішення проблем. Стаття присвячена творчому потенціалу співробітників і аналізу застосовуваних методів та інструментів управління, які сприяють творчості. Незалежно від того, у якій сфері діє компанія, оскільки місія компанії визначається в креативності, інноваціях і здатності компанії працювати ефекттивно та гнучко. Компанія використовує креативність, щоб зміцнити свої позиції на ринку і створити конкурентні переваги. Показувши результати наших досліджень, ми узагальнимо характеристики компанії, а також представимо наші висновки з дослідження.

Ключові слова: менеджмент, творчість, підвищення творчості, сільськогосподарський сектор, Словаччина.

C.T. Косар, PhDr., экономический факультет, Университет им. Яноша Шейе (г. Комарно, Словакия);

P. Махова, Ing., экономический факультет, Университет им. Яноша Шейе (г. Комарно, Словакия);

М. Шимонова, Mgr., экономический факультет, Университет им. Яноша Шейе (г. Комарно, Словакия)

Творчество в практике в контексте прикладных методов и инструментов управления

Менеджмент как дисциплина является частью человеческой чивилизации во многих аспектах ее природы, а управленческое творчество как основной источник бизнес-инноваций приобрело исключительное значение в XXI веке. Использование экономических и людских ресурсов возможно за счет увеличения творчества и активизации инновационного потенциала людей. Творчество - это столп инноваций, который помогает организациям разрабатывать бизнес-стратегии и способствует укреплению рыночных позиций организации, а также отличает ее от других. Использование инструментов управления имеет большое значение для улучшения рабочего процесса, обеспечения эффрективной работы компании и успешного решения проблем. Статья посвящена творческому потенциалу сотрудников и анализу применяемых методов и инструментов управления, способствующих творчеству. Независимо от того, в какой области компания работает, поскольку миссия компании определяется в креативности, инновациях и способности компании работать эфрфективно и гибко. Компания использует креативность, чтобь укрепить свои позиции на рынке и создать конкурентные преимущества. Показывая результаты наших исследований, мы обобщим характеристики компании, а также представим наши вывод исследования.

Ключевые слова: менеджмент, творчество, повышение творчества, сельскохозяйственный сектор, Словакия.

Отримано 15.12.2016 p. 